\title{
Depositors' Assessment of Bank Riskiness in the Russian Federation
}

\author{
Ece Ungan · Selçuk Caner · Süheyla Özyıldırım
}

Received: 27 July 2006 / Revised: 7 November 2007 /

Accepted: 16 November 2007 / Published online: 20 December 2007

(C) Springer Science + Business Media, LLC 2007

\begin{abstract}
In the period after the crises in the late 1990s, the banking industries in most emerging markets have undergone significant restructuring consistent with the Basel II Accord. The Central Bank of Russia's efforts since 2000 have contributed to the consolidation and improvement of the banking industry. To measure the extent of market discipline in the Russian banking industry, we study the reaction of Russian depositors to excessive risk taking by large banks between 2000:1 and 2005:1. We find that during our analysis period, well-capitalized, more liquid banks significantly increase their deposits.
\end{abstract}

Keywords Market discipline • bank risk • emerging markets • Russian Federation

JEL Classifications G20 - G21

\section{Introduction}

The New Basel Accord of 2001 introduced guidelines for all major banks that promoted safety, competition, and a comprehensive approach to assessing risktaking. The Accord framework envisions minimum risk-based capital requirements, adequate supervisory reviews, and market discipline as the three pillars of a banking system. Moreover, the preconditions for the existence of a sound banking system, as outlined by the Bank for International Settlements (BIS), are sustainable sound

We would like thank to the participants in the seminar at 7 th International Scientific Conference Modernization of the Economy and the State, HSE, Moscow, Russian Federation for their comments and suggestions. We thank the editor and the two anonymous reviewers for their invaluable comments.

E. Ungan · S. Caner $(\varangle) \cdot$ S. Özyıldırım Faculty of Business Administration, Bilkent University, Bilkent 06800, Ankara, Turkey e-mail: caner@bilkent.edu.tr 
macroeconomic policies, a safety net for the public that funds the banking system, and an efficient system of resolution of banks.

The Accord addresses the need for stakeholders to exert market discipline on banks, which is especially important in jurisdictions such as Russia, where it is difficult to impose minimum capital requirements and implement effective bank supervision. Notably, depositors' monitoring and disciplining of the banks can restrain disproportionate risk taking. Further, as depositors monitor bank riskiness, they can reallocate their funds within the banking industry away from riskier banks.

Since 1998, the Russian banking industry has undergone significant changes both in terms of a reduction in the number of banks as well as in establishing public confidence in the use of the banking system for financial intermediation. As of 2005 , there are 1,253 banks, down from a high of over 3,300 in 1995, distributed over a very large geography that makes it difficult to supervise and monitor. In such a banking system with a large number of banks, market discipline imposed by depositors can be useful in regulating bank risk-taking behavior. In addition, market discipline increases competitiveness in the banking industry as depositors increase the flow of funds to banks that avoid excessive risk taking. By providing more accurate, freely available information about the banks' financials, the banking industry in the Russian Federation benefits from depositor discipline.

To measure the extent of market discipline in the Russian banking industry we study the reaction of Russian depositors to excessive risk taking by banks during the period 2000:1 to 2005:1. However, the Russian banking industry consists of many banks that are not comparable to commercial banks operating in other market economies. Therefore, we include in our sample banks with assets of more than $\$ 50$ million, which accounts for $96 \%$ of all deposits in the industry.

We test whether depositors withdraw their funds or demand higher interest rates in response to high risk-taking by banks. In addition, we account for the effects of other factors on deposits, such as economic factors and the deposit insurance system introduced in 2004.

We find that during our analysis period, banks significantly increase their deposits in response to increases in capital and liquidity. These results indicate that depositors exercise market discipline by changes in deposits. In other countries, there is evidence that interest rates also play a disciplining role.

To understand the factors that contribute to the difference between the Russian banking industry and banks in other countries, we analyze banks by categorizing them according to their level of capitalization and liquidity. We present evidence that market discipline exists for undercapitalized and low-liquidity banks. For wellcapitalized and liquid banks, depositors do not see any need to monitor the risktaking behavior. This behavior may be due to explicit guarantees for state-owned banks and implicit guarantees for large sound banks. But even large banks with less capital and liquidity are subject to discipline by depositors, as demonstrated by the sensitivity of deposits to bank risk factors such as capital and liquidity adequacy and membership in the deposit insurance system.

The paper is organized as follows. In Section 2 we provide a brief review of studies on various forms of market discipline in both developed and emerging markets. In Section 3 we briefly review the Russian banking industry. In Section 4 we present our model for estimating the equations of depositor discipline. We describe the data in Section 5. In Section 6, we discuss the estimation results. Section 7 concludes. 


\section{Literature Review}

Asset prices are effective mechanisms for conveying information about the wealth maximizing motives of economic agents. Using asset prices, market participants can restrict the volume and cost of funding to signal unattractive risk-return trade-offs.

Market discipline describes a situation in which private sector agents, such as equity holders and debtholders, produce information that helps supervisors to recognize problem banks and implement corrective measures. Bliss and Flannery (2002) identify two distinct components of market discipline as "monitoring" and "influencing." Monitoring occurs when investors incorporate changes in a firm's risk taking in stock or bond prices. Influencing refers to the ability of market participants to affect a firm's financial decisions. Berger (1991) states that bank stakeholders face costs that increase as firms undertake risks, and that stakeholders, i.e., depositors, shareholders, and creditors, take action because of these costs. There are three broad classes of market reactions. First, depositors may require higher interest rates. Second, investors may withdraw uninsured funds from the bank. Third, the bank may be forced to restore its financial condition.

Calomiris and Kahn (1991) formally define market discipline as depositors having the incentive to monitor the bank and prematurely withdraw their demandable deposits. They emphasize that the depositors do not just price the risk (risk averse) they also act to limit it (risk intolerant). Flannery (1998) points out that the liability markets for the banks are sensitive to the changes in banks' financial conditions, and that investors identify and act according to the default risk changes.

Recent research, such as that by Barth et al. (2002, 2003, 2004), on cross-country supervisory frameworks emphasizes the importance and the need for enhanced transparency that can be obtained by the disclosure of relevant information and the reinforcement of market discipline. Empirical evidence supports market discipline that is based on improved financial information disclosures, and enhancing market participants' ability to assess and control banks' risks in the U.S. and Europe. For example, Gilbert (1990) surveys early literature on market discipline. Flannery (1998, 2001), Sironi (2002), and Flannery and Nikolova (2004) provide contemporary literature surveys.

In addition, market discipline can be established by using the relation between risk indicators and subordinated debt yields or large deposit rates. Risk premia on subordinated notes and debentures are correlated with accounting risk measures, asset portfolio composition, credit agency or regulatory ratings, and the probability of failure. Jagtiani and Lemieux (2001), Morgan and Stiroh (2001), Sironi (2002), Evanoff and Wall (2002), and Jagtiani et al. (2002) are among the recent examples of such studies.

As an alternative to subordinated debt, Hall et al. (2002) document a positive relation between the yields on certificates of deposits (CDs) and the riskiness of the banks that have a satisfactory regulatory rating. However, using a sample of bank holding companies with failing subsidiaries, Jagtiani and Lemieux (2001) find no evidence of market discipline in the uninsured CD market. Furfine (2001) provides evidence of market discipline in the overnight federal funds market, where creditors require interest rates dependent on the credit risk of the borrowers.

Market discipline can also take the form of decreases in the availability of uninsured funds, because investors will withdraw their funds if they believe that 
the bank is becoming more risky. Furthermore, the higher borrowing costs of the uninsured funds may force the banks to shift to insured funds. Consistent with market discipline, Billet et al. (1998), Jagtiani and Lemieux (2001), and Hall et al. (2002) show that as the financial condition of the bank worsens their reliance on insured funds increases. Goldberg and Hudgins (1996, 2000) and Park and Peristiani (1998) provide similar results for thrifts.

Banks are the dominant financial intermediaries in emerging markets. In addition to the opacity of ordinary banking activities, frequent financial crises, state ownership of banks, and inadequate supervision necessitate close monitoring of financial institutions by the market. Market discipline by shareholders, creditors, and depositors can control the risk-taking behavior of banks. Although in most developed financial markets, shareholders demonstrate through the market value of the bank their assessment of a publicly traded bank's risk-taking, market prices have either no role at all, or else only a very limited one, in emerging markets. In such markets banks are either privately held or the traded shares are a very small portion of the outstanding bank shares. And even if the bank stocks are traded, the number of shares held by outside shareholders is usually very small. For example, the only bank stock traded in the Russian Trading System (RTS) is the state-owned Sberbank. The shares traded represent only a very small portion of the outstanding shares. A very large majority of shares are held by the Ministry of Finance and the Central Bank of Russia.

Furthermore, in developing financial markets, there is very little subordinated debt that is valued in secondary markets. Lack of subordinated debt reflects banking industry riskiness. Thus, in countries where the availability of instruments for market discipline is limited due to inadequate publicly traded bank equity or subordinated debt, depositors are the primary source for disciplining bank risk-taking behavior. Therefore, the combination of government regulation and supervision and monitoring by depositors can result in high-quality banks that are conducive to financial intermediation without risking depositors funds.

Empirical studies on market discipline for developing countries focus on the behavior of depositors. Most of the evidence on the existence and efficacy of market discipline comes from Latin America. Calomiris and Powell (2001) find that in Argentina, high asset risk and leverage are associated with greater deposit withdrawals and, high asset risk is reflected in higher deposit interest rates. Barajas and Steiner (2000) study market discipline by depositors in Colombia. They show that the depositors prefer banks with strong fundamentals, namely, high capitalization, liquidity, low non-performing loans and profitability. Martinez-Peria and Schmukler (2001) test interaction in the 1980s and the 1990s between market discipline and deposit insurance and the impact of banking crises on market discipline in Argentine, Mexico, and Chile. Their findings support the view that there is market discipline across all three countries. Depositors reduce the level of their deposits and increase the interest rates demanded from those banks undertaking high risks. Their results also suggest that the deposit insurance in these three countries is not fully credible and both insured and uninsured depositors exercise market discipline. Moreover, the evidence shows that market discipline by depositors separately increased in Argentina, Chile, and Mexico following bank crises in those countries.

In a study on depositor discipline in India, Ghosh and Das (2003) focus on the Indian banking industry during the 1990s, after the liberalization of the banking sector. Bank fundamentals are significant in determining the changes in deposits and 
interest paid. Therefore, the authors argue that depositors in India punish banks for risky behavior during the analysis period.

Ungan and Caner (2004) study market discipline in Turkey. They estimate that there is evidence of market discipline in the Turkish banking industry in the 19882003 period. They observe that uninsured depositors closely monitored the risk indicators obtained from financial data. However, the introduction of full deposit insurance ceased the monitoring motives for both insured and uninsured depositors.

There are few studies that analyze depositor discipline in the transition economies. Mondschean and Opiela (1999) provide findings on market discipline in Poland during 1992-1996. Their results suggest that the depositors demand higher interest rates for risky banks before the changes in the insurance scheme, and that the fully insured banks pay lower interest rates. Moreover, the state-owned banks have both implicit and explicit coverage. They conclude that the full deposit insurance scheme and government ownership of Polish banks reduces the monitoring incentives of the market participants. Recently, Karas et al. (2004) examine market discipline in the Russian deposit market for the period 1997-2002. ${ }^{1}$

\section{The Russian Banking Industry}

During the Soviet period, when the economy was state-controlled and centrally planned, the government owned and managed the banking system in the Russian Federation. Gosbank was not only the central bank, but also the only commercial bank. Savings were kept in another state-owned bank, Sberbank. There were also two other state banks, Vneshtorgbank, which handled foreign trade transactions, and Stroybank, which provided investment credits for enterprises. Following the economic reforms to establish a market-based system in 1991, the Russian banking system has evolved into a two-tier system that includes both the central bank and the commercial banks.

Until 1995, the regulation of the commercial banks by the Central Bank of Russia (CBR) was quite lax, which led to the existence of numerous commercial banks of questionable quality. By the end of 1995, there were over 3,300 banks, most of which were small and undercapitalized. Many banks were financially linked to companies and provided subsidized credits.

The Russian banking system was shaken by the financial crisis of 1998. Repayments of private and public external debt were temporarily frozen. Devaluation of the ruble and low levels of liquidity led to the bankruptcy of many banks. However, Russian banks had had serious problems before the 1998 crisis, primarily due to poor capitalization, low liquidity, and high exposure to exchange-rate risk. Further, they were reluctant to act as intermediaries between borrowers and savers for several reasons. First, there was a large informational asymmetry between the banks and the customers. Second, the banks were not equipped with the screening and monitoring skills needed to avoid credit risks. They were not able to differentiate credit risks of potential borrowers. Third, banks could not reclaim their loans due to the weak

\footnotetext{
${ }^{1}$ These authors provide evidence for market discipline by using all operating credit institutions' data. Thus, the significance of their results varies by the subperiods chosen and types of depositors.
} 
rule of law and enforcement. Fourth, some of the small banks were purchased by newly established undercapitalized enterprises to be used as their "pocket banks," i.e., banks that facilitate borrowing by owners at favorable terms, and which can also be used in reducing the tax liability of the owners. Consequently, there was no real banking industry in the earlier years after the break up of the Soviet Union. Further, few banks were able to operate at the national level. Moreover, many banks do not have branches in the regions of the Russian Federation.

During the financial crisis in 1998, many banks were either bankrupt or liquidated. Most of the illiquid banks were allowed to operate until March 1999 when the CBR started restructuring the Russian banking system. By the end of the first half of 2005, the Russian economy had experienced seven years of robust economic growth and the Russian banking industry had also recovered.

Since 2002, CBR has strengthened the financial conditions in the banking industry by issuing new prudential regulations. With the introduction of the deposit insurance system in 2004, prudential standards were further strengthened. The introduction of the deposit insurance system created an opportunity for the CBR to thoroughly examine all the banks. Deposit insurance, introduced in 2004, has limited power in terms of supervision and regulating banks. These functions exclusively remain at the CBR. So, the newly established deposit insurance agency operates like a cash box. In 2005, the Agency was also given authority to liquidate banks.

With the anticipation of a membership in the deposit insurance system, many banks started to improve their balance sheets long before the CBR examined them. Banks that were admitted to the new deposit insurance scheme after being examined by the CBR account for $98 \%$ of deposits. Nevertheless, key problems, such as strengthening creditor rights and expanding the implementation of International Accounting Standards (IAS), still need to be addressed.

In Table 1 we present aggregate measures of the Russian banking sector from 2000 to 2005 . The asset-to-GDP ratio of banks increased from $31 \%$ in 2000 to $45.1 \%$

Table 1 Russian banking sector

\begin{tabular}{lcccccc}
\hline & 2000 & 2001 & 2002 & 2003 & 2004 & 2005 \\
\hline $\begin{array}{l}\text { Nominal GDP (billion rubles) } \\
\text { Total banking sector }\end{array}$ & $7,302.2$ & $8,944.0$ & $10,818.0$ & $13,201.0$ & $16,779.0$ & 21,617 \\
$\quad \begin{array}{l}\text { assets (nominal, billion rubles) } \\
\text { Share of GDP }\end{array}$ & $2,260.9$ & $3,159.7$ & $4,145.3$ & $5,600.7$ & $7,136.9$ & 9,750 \\
$\quad$ Total assets & 30.96 & 35.33 & 38.32 & 42.43 & 42.53 & 45.10 \\
$\quad$ Total capital & & 5.07 & 5.37 & 6.17 & 5.64 & 5.70 \\
$\quad$ Total loans & & 13.16 & 14.71 & 17.17 & 18.77 & 19.0 \\
$\quad$ Total deposits & 9.53 & 7.58 & 9.52 & 11.47 & 11.71 & 12.81 \\
$\quad$ Other bank funds & & 10.09 & 10.09 & 10.49 & 11.84 & 13.73 \\
Share of total assets & & 14.37 & 14.02 & 14.55 & 13.26 & 12.64 \\
$\quad$ Total capital & & 37.24 & 38.39 & 40.48 & 44.14 & 42.20 \\
$\quad$ Total loans & 30.78 & 21.45 & 24.84 & 27.04 & 27.52 & 28.31 \\
$\quad$ Total deposits & & 28.57 & 26.33 & 24.73 & 27.83 & 30.30 \\
$\quad$ Other bank funds & & & & & & \\
\hline
\end{tabular}

${ }^{a}$ Includes only household deposits.

${ }^{b}$ Other bank funds are mainly funds obtained from other bank and non-bank financial institutions. Source: Central Bank of the Russian Federation Banking Supervision Report 2004. 
in 2005. Meanwhile, capital ratios remained more or less the same. Banks were able to expand their loan portfolios as demand from the corporate sector and households increased. As of the end of 2005 there were 1,253 active banks, of which 32 were state banks. The number of foreign banks increased to 51 .

The number of branches declined from 3,793 to 3,295 (see Fig. 1). Most of the decline is due to Sberbank's closing of branches in major urban areas. However, the second largest state bank, Vneshtogbank, and foreign banks increased the number of their branches during the same period.

The Russian banking industry started facing competition from foreign banks after 2004. Furthermore, foreign banks paid higher interest rates compared to other banks, which increased their market share.

The Central Bank of the Russian Federation classifies banks according to ownership, type of funding, clientele, and risk characteristics. Table 2 demonstrates the bank clusters identified by the CBR and their shares of assets and capital. Stateowned banks provided $40.7 \%$ of assets and $33.8 \%$ of capital in the banking industry. State-owned banks and diversified banks jointly provide about $70 \%$ of the total corporate loans, with state-owned banks' share at about $47 \%$. These two groups of banks also provided $75 \%$ of loans to the households.

The CBR defines intragroup banks as those banks controlled by one or few related owners. These banks are also characterized by recurring large loans to few borrowers. The largest groups of banks are small and medium-sized banks in the Moscow region. However, their shares of total banking industry assets and capital remain small.

Since 2004, as a source of funding, long-term borrowing and corporate deposits have grown faster than household deposits. Corporate deposit growth is mainly in diversified banks, state-owned banks and the foreign-owned banks. Moreover, due to their good international credit ratings, state-owned and diversified banks have been

\section{Number of Banks and Branches}

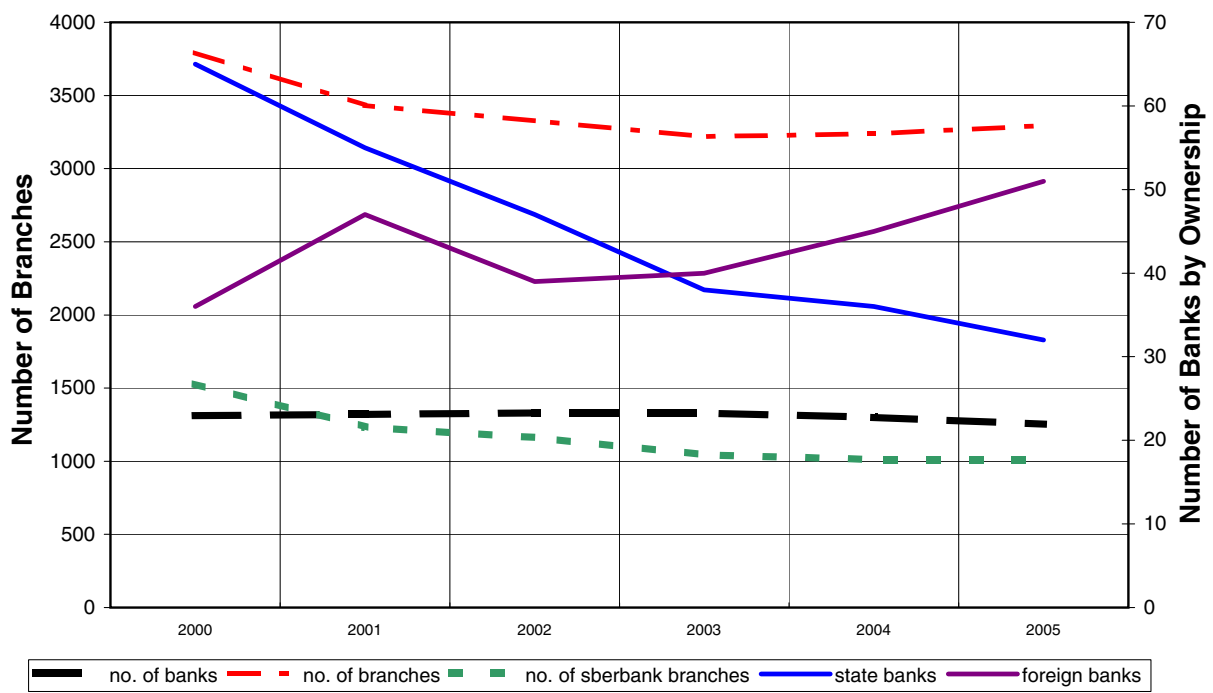

Figure 1 Number of banks and branches 
Table 2 The clustering of Russian banks

\begin{tabular}{lccc}
\hline Credit institutions & Number & $\begin{array}{l}\text { Share of } \\
\text { total assets }\end{array}$ & $\begin{array}{l}\text { Share of } \\
\text { total capital }\end{array}$ \\
\hline State-controlled banks & 32 & 40.7 & 33.8 \\
Foreign-controlled banks & 51 & 8.3 & 9.2 \\
Intra-group banks $^{\text {a }}$ & 109 & 16.2 & 19.4 \\
Diversified banks $^{\text {b }}$ & 74 & 25.1 & 23.4 \\
Small and medium banks in Moscow & 455 & 5.1 & 8.6 \\
Regional small and medium banks & 484 & 4.2 & 5.4 \\
Non-bank credit institutions & 48 & 0.5 & 0.2 \\
Total & 1,253 & 100.0 & 100.0 \\
\hline
\end{tabular}

${ }^{\mathrm{a}}$ Intra-group banks are those controlled by several related owners. CBR identifies them according to large loans per borrower and preferential lending.

${ }^{\mathrm{b}}$ Diversified banks are large banks neither controlled by the state nor foreign-owned and do not belong to intra-groups. Source: Central Bank, Bank Supervision Report, 2005.

able to raise funds in the international interbank market, thus reducing their reliance on deposits. As a result, Sberbank's share of household deposits declined from $60 \%$ to $54 \%$. However, half of this decline was captured by another state-owned bank, Vneshtorgkbank.

Foreign banks also experienced large increases in household deposits. We note that in the Moscow region and other regions, the small and medium-sized banks that were admitted to the deposit insurance system observed the least growth in their household deposits.

According to CBR (2006), the banking industry is concentrated in the deposit market. The top 200 banks (16\% of all banks), which the CBR uses as a benchmark, account for $89.6 \%$ of the total bank assets and $85 \%$ of the industry's total capital. The biggest bank, Sberbank, accounts for $28.6 \%$ of all banking industry assets, $54 \%$ of deposits and $33 \%$ of total equity in the banking industry.

The top five banks' share in terms of assets in banking industry declined from $45 \%$ in 2003 to $43.8 \%$ in 2005 . During the same period, the share of top five banks in total banking industry's equity increased from 34 to $36 \%$. Furthermore, the number of banks with excess capital over the statutory capital amount of 5 million euro increased from 501 to 602 . Thus, since 2004 banks have increasingly relied on their own funds and corporate deposits to fund asset acquisition.

The Russian banking industry has low levels of concentration in terms of assets, loans, and capital. However, household deposits continue to be concentrated despite a steady decline observed in the last three years. We use the Herfindahl-Hirschman index (HHI) to measure concentration levels for assets. The HHI ranges between zero and one. HHI less than 0.1 are considered low concentration, 0.1 to 0.2 is medium, and over 0.2 is considered high concentration. We find that this level is about 0.09 and fairly stable (CBR 2005). We estimate the HHI for loans at 0.12 in 2005, up from 0.105 in 2004. The concentration ratio for capital is at 0.05 in 2005 . The HHI concentration value for household deposits is 0.3 in 2005, down from 0.4 in 2004.

These estimates indicate a high concentration in the deposit market. The decline in the concentration of deposits is primarily due to the reduction in the deposits in Sberbank. The government plans to sell the remaining state-owned shares once 
Sberbank's share of total deposits decline to less than $50 \%$ possibly, in 2008 . Thus, we can expect further decline in deposit concentration.

Although it is declining, high-concentration ratios for deposits imply depositor discipline in banks in the Russian Federation. Households that place their deposits in few large banks demonstrate that it is safer to deposit in few large banks and enjoy the guarantees on deposits. Furthermore, despite the growth in the utilization of banking services, the infancy of the deposit insurance system might have increased the tendency of depositors to put their savings in larger banks and benefit from "too big to fail" protection.

\section{Empirical Model}

To determine the extent of depositor discipline in Russian Federation, we estimate the response of depositors to excessive bank risk-taking during the period 2000:1 to 2005:1, using the following model:

$$
\begin{aligned}
Z_{j, t}^{i}= & \alpha_{j}+\sum_{j=1}^{2} \beta_{j} Z_{j,(t-1)}^{i}+\sum_{k=1}^{5} \phi_{j, k} \operatorname{Risk}_{k,(t-1)}^{i}+\sum_{p=1}^{2} \gamma_{j, p} \text { Macro }_{p,(t-1)} \\
& +\sum_{q=1}^{2} \delta_{j, q} \operatorname{Bank}_{q, t}^{i}+\sum_{l=1}^{2} \psi_{j, l} \operatorname{Size}_{l,(t-1)}^{i}+\varphi_{j} \text { DI Dummy }_{t} \\
& +\sum_{k=1}^{5} \theta_{j, k} \operatorname{Risk}_{k,(t-1)}^{i} \cdot \text { DI Dummy } \\
& +\sum_{l=1}^{2} \lambda_{j, l} \operatorname{Size}_{l,(t-1)}^{i} \cdot \text { DI Dummy }_{t}+u_{i, t}
\end{aligned}
$$

where $u_{i, t}$ is the error term.

Depositors' assessment of bank riskiness is measured by the percentage change in the deposits of bank $i$ at time $t\left(Z_{1, t}^{i}\right)$, and by the deposit interest rate paid by bank $i$ at time $t\left(Z_{2, t}^{i}\right)$. The interest rate we use as a dependent variable is the implicit interest rate, which we calculate as the ratio of interest expense to total deposits in the previous period. ${ }^{2}$ The model described in Eq. 1 is a reduced-form specification of deposit demand and supply relation. We include the lagged dependent variables to account for the simultaneity of the change in deposits and the interest rates.

We include five factors in the estimations as the sources of risk. As our proxy for bank riskiness $\left(\operatorname{Risk}_{k, t}^{i}\right)$, we use the following financial ratios: nonperforming loanto-assets, loans-to-assets, capital-to-asset, net profit after tax-to-assets, and liquid

\footnotetext{
${ }^{2}$ Similar to previous studies on market discipline (e.g., Martinez-Peria and Schmukler 2001 for Argentina, Chile, and Mexico; and Mondschean and Opiela (1999) for Poland) we use the average interest rate on deposits to test the reaction of the Russian depositors to banks' risk-taking. Theoretically, marginal rates indicate the sensitivity of deposit rates to change in bank riskiness, but because marginal deposit rates are not available, we use implicit interest rates. However, since the majority of deposits are short-term in the Russian Federation, we argue that the difference would not be significant enough to alter results. Nevertheless, we note that to understand how deposit rates are determined in the Russian Federation, Peresetsky et al. (2006) use marginal interest rates for selected banks, and find results similar to those in our study.
} 
assets-to-assets. We control for macroeconomic impacts $\left(\mathrm{Macro}_{p, t}\right)$ by changes in the consumer price index (CPI) and the dollar-ruble exchange rate. Two dummy variables that account for the state and foreign ownership describe bank ownership status $\left(\operatorname{Bank}_{q, t}^{i}\right)$. Size of the bank $\left(\operatorname{Size}_{l, t}^{i}\right)$ is characterized by two variables: the natural logarithm of total asset size of a bank and the relative size of the bank's total deposits in its total funding base. The bank's total funding base includes deposits, interbank loans, and long-term debt. DI Dummy is a time dummy that identifies periods of deposit insurance after its introduction in the second half of 2004.

Similar to other studies on market discipline, we expect that an increase in the ratio of both nonperforming loans to assets and loans to assets will negatively affect deposit growth. On the other hand, increasing riskiness that is due to high nonperforming loans and indebtedness, will positively affect the interest paid on deposits. Increases in capital-to-asset, net profit after tax-to-assets, and liquid assetsto-assets ratios indicate a reduction in the riskiness of banks.

\section{Data}

We obtain quarterly bank-level data from data services provider Mobile Information Services for the period from 2000:1 to 2005:1. Considering major macroeconomic fluctuations and reporting quality, we use the data after 1999. We exclude the crisis year of 1998 and its aftermath.

The 2000-2005 period, is a financially stable period for the Russian financial markets. In 2002, CBR introduced new regulations to improve reporting by banks. Thus, the quality of the financial statements is substantially better than prior years. Since 2004, CBR has required that banks use the new method to calculate the capital and liquidity adequacy ratios.

The data set includes 1,461 commercial banks operating in the Russian Federation during the 2000-2005 period. The asset size of banks varies from $\$ 2$ billion for the largest bank to less than $\$ 10,000$. We estimate depositors' market discipline by using two separate groups of banks. We exclude small banks because $96 \%$ of deposits are placed in large banks. In most cases, small banks have few depositors, and often, those few depositors are either the owners, a large firm, or local administrations. Therefore, it is very unlikely that external depositors might influence on small banks' risk taking.

The first data set comprises only the biggest 50 banks in the Russia Federation, as determined by total asset size in 2005. The second data set comprises 377 banks with total assets of more than $\$ 50$ million in 2005 . We exclude eight of the banks from the data set because of an insufficient amount of consecutive financial information during the analysis period. Therefore, in the data set we use only 369 banks for estimation purposes.

In Table 3, we report the nominal amount and industry shares of total assets, loans, deposits and capital. We label banks with total assets greater than $\$ 50$ million as "Big Banks." Big Banks account for about $95 \%$ of the total assets and loans, for $96 \%$ of total deposits, and $90 \%$ of the total capital in the Russian banking industry. 
Table 3 Summary of banks' balance sheet activities as of March 2005

\begin{tabular}{|c|c|c|c|c|c|c|c|c|}
\hline \multirow[t]{2}{*}{ Banks } & \multicolumn{2}{|c|}{ Total assets } & \multicolumn{2}{|c|}{ Total loans } & \multicolumn{2}{|c|}{ Total deposits } & \multicolumn{2}{|c|}{ Total capital } \\
\hline & $\begin{array}{l}\text { Billion } \\
\text { rubles }\end{array}$ & Percent $^{\mathrm{a}}$ & $\begin{array}{l}\text { Billion } \\
\text { rubles }\end{array}$ & Percent & $\begin{array}{c}\text { Billion } \\
\text { rubles }\end{array}$ & Percent & $\begin{array}{c}\text { Billion } \\
\text { rubles }\end{array}$ & Percent \\
\hline All & 7,089 & 100 & 3,635 & 100 & 2,439 & 100 & 939 & 100 \\
\hline Top 50 banks ${ }^{b}$ & 5,226 & 74 & 2,778 & 76 & 1,993 & 82 & 578 & 62 \\
\hline Big banks ${ }^{c}$ & 6,706 & 95 & 3,464 & 95 & 2,353 & 96 & 842 & 90 \\
\hline
\end{tabular}

ashare in the Russian Banking industry.

b“Top 50 Banks” by asset size.

${ }^{\mathrm{c}}$ Assets above $\$ 50$ million.

We analyze depositor discipline of the "Top 50 Banks" separately, since these banks are the money-center banks that dominate the Russian economy. Top 50 Banks represent $74 \%$ of the assets and $76 \%$ of total loans made by the banking industry, and account for $82 \%$ of the deposits and $62 \%$ of the capital of the banking industry.

Table 4 shows the descriptive statistics for both the Big Banks and the Top 50 Banks. On average, the Top 50 Banks pay lower implicit interest rates on deposits compared to the Big Banks. Consequently, these banks are relatively less successful in attracting new deposits. The Big Banks average growth rate in deposits is $16.65 \%$, but only $14.92 \%$ for the Top 50 Banks. As a share of assets, net nonperforming loans are marginally lower for the Top 50 Banks. Although the Top 50 Banks operate with lower capitalization and liquidity, they are more profitable than the Big Banks with assets of $\$ 50$ million or more.

Table 4 Descriptive Statistics for the Period 2000:1-2005:1

\begin{tabular}{|c|c|c|c|c|}
\hline & \multicolumn{2}{|c|}{$\begin{array}{l}\text { Banks with assets } \\
>\$ 50 \text { million }(N=369)\end{array}$} & \multicolumn{2}{|c|}{$\begin{array}{l}\text { Top } 50 \text { banks } \\
(N=50)\end{array}$} \\
\hline & Mean & Std Dev & Mean & Std Dev \\
\hline \multicolumn{5}{|l|}{ Dependent variables } \\
\hline Growth in deposits (\%) & 16.65 & 65.58 & 14.92 & 52.29 \\
\hline Implicit interest rate $(\%)$ & 13.00 & 113.66 & 9.3 & 30.78 \\
\hline \multicolumn{5}{|l|}{ Bank risk variables } \\
\hline Non-performing loans/total assets (\%) & 0.13 & 0.52 & 0.12 & 0.37 \\
\hline Total loans/total assets $(\%)$ & 37.24 & 18.35 & 39.32 & 17.36 \\
\hline Total capital/total assets $(\%)$ & 21.36 & 14.26 & 16.71 & 10.15 \\
\hline Net profit after tax/total assets (\%) & 2.14 & 2.77 & 2.53 & 2.76 \\
\hline Liquid assets/total assets (\%) & 44.06 & 26.91 & 43.54 & 60.02 \\
\hline \multicolumn{5}{|l|}{ Size variables } \\
\hline Total assets (in natural logarithm) & 21.46 & 1.5 & 23.72 & 1.41 \\
\hline Total deposits/total funding base (\%) & 92.52 & 18.87 & 85.50 & 23.98 \\
\hline
\end{tabular}

Source: Mobile Information Services. 


\section{Estimation Results of Depositor Discipline}

We estimate the empirical model described in Eq. 1 using pooled cross-sectional time series data for our sample period. First, we estimate the model using ordinary least squares (OLS) for all banks. Then, to account for the differences across individual banks, we estimate the fixed-effect model, which captures the differences by the constant terms for each member of the panel data. We note that because there are many banks in the Russian Federation, we could not estimate the fixed-effect model for all banks.

Table 5 presents the parameter estimates, both with OLS and the fixed-effect model for the deposit growth equation. In Table 5, column 1 shows the parameter estimates for all banks, columns 2 and 3 the parameter estimates for Big Banks, and columns 4 and 5 the parameter estimates of Top 50 Banks. The difference in estimated parameters between all banks and the large banks can be attributed to the small banks. We observe that the effect of small banks on estimated parameters for lagged deposit growth rates and interest rates are not different from those of the large banks, both in terms of sign and size. If the deposit accumulation rate is high in the previous period, then there is a significant slowdown in the deposit growth of both small and large banks. Moreover, if banks offer higher interest rates in the previous period, then the funds deposited in these banks increases significantly.

For all three data sets we find that two risk factors have a significant effect on the deposit growth during the sample period. We find that higher capital-toasset and higher liquid assets-to-asset ratios increase growth in deposits, implying depositors' preference for well-capitalized and highly liquid banks. In fact, only the OLS estimation of capital-to-asset ratio is not significant for the Top 50 Banks group. These findings also suggest that the ability to access their funds any time is significantly important for the depositors in the Russian Federation.

Higher loans-to-asset ratios for large banks, and especially the ratios for the Top 50 Banks, have a positive effect on deposit growth. Total loans are only significant in the OLS estimates of large banks at the $10 \%$ level, but have the wrong sign. For the Top 50 Banks, loans are significant at $5 \%$ but again have the wrong sign. Since we use the loans-to-asset ratio as our proxy for credit risk, this result is not consistent with our expectations. The positive sign of the loan-to-asset ratio implies that depositors do not perceive loan expansion as a risk factor. Perhaps depositors view the financing of profitable loans by nondeposit sources as a benefit in terms of higher interest earnings. Consequently, depositors do not consider growth in loans financed by different sources as a risk to their savings.

The significant positive relation between deposit growth and the higher loans-toasset ratio for the Top 50 Banks indicates their ability to find international funding that is cheaper than domestic deposits. Most of the Top 50 Banks have good credit ratings and have no difficulty in obtaining funds from corporations and international banks.

The estimated parameter of interaction dummies with deposit insurance shows that the introduction of deposit insurance alters the behavior of small-bank depositors. Since the interaction dummies of all banks turns to be nonsignificant for all risk factors, we argue that deposit insurance impairs the efforts of depositors to discipline small banks. Nevertheless, depositors who use large banks continue to seek banks with high capital-to-assets ratios. Furthermore, since the introduction of 
deposit insurance, depositors to the Top 50 Banks evidently prefer profitable banks. The general public has not been aware of the full benefits of deposit insurance and also, banks have not aggressively publicized the benefits of being a member bank in the insurance system. It is possible that sufficient time has not elapsed for depositors to assess banks since the introduction of the deposit insurance system, and then to diversify their deposits. In addition, in admitting the qualifying banks to the insurance system, CBR may have been biased in favor of well-capitalized banks.

State ownership is not a major factor in determining deposit growth. Among the Top 50 Banks, depositors prefer state banks; however, this result is only supported in the OLS estimation. In addition, size is only significant with the correct sign for banks with assets of more than $\$ 50$ million. Since these are all big banks, this variable is not significant for the Top 50 Banks.

Table 6 presents the estimated parameters of risk factors affecting interest rates on deposits. When banks observe increases in deposits in the previous period, they reduce current interest payments on deposits. However, the magnitude of the response of small banks is much bigger compared to large banks. Small banks are compelled to reduce deposits due to limited ability to allocate excess funds.

Further, banks follow the trend in interest rate on deposits paying higher interest rates if interest rates are on the rise in the previous period. They continue to offer same interest rates on deposits however at a decreasing rate. We do not observe a difference in the response of small and large banks.

For the Top 50 Banks, we find that the capital-to-assets ratio, liquidity ratio, and profitability significantly affect the interest rates paid on deposits. However, the signs of the parameters indicate that less risky banks, i.e., banks that can increase their capitalization, liquidity, and profitability, pay higher interest rates during the analysis period. These findings imply that to a great extent, large banks that do not want to lose market share on deposits to growing, mid-sized, and foreign banks determine interest rates. Because the capital-to-assets ratios of the large banks are already relatively low (see Table 4), the large banks use deposits more as a major source of funding. We also observe that foreign banks in the Top 50 Banks group pay significantly higher interest rates on deposits to increase market share in the domestic deposit market.

As Table 6 shows, size plays a significant role in the determination of the interest rates on deposits: as the asset size increases, large banks pay lower interest rates, but in contrast, small banks pay higher rates. This conflicting pricing by banks of different sizes indicates the small banks' efforts to attract more deposits, thus improving their inadequate source of external funds from depositors. Since there has been a decrease in the accumulation of deposits in the large banks since 2001 (mainly the decline of Sberbank's share), small banks have had to pay a price to obtain more deposits.

The introduction of deposit insurance provided an opportunity for banks to improve their financial balances. The coefficients of the interaction dummies show that large banks with adequate capitalization were able to reduce interest expenses once they were admitted to the deposit insurance system. Once admitted to the deposit insurance system, small banks tried to attract deposits by offering higher interest rates.

Membership in the deposit insurance system also requires increases in the capital for many small banks. Until 2005, more than half of the banks had equity of less than $€ 5$ million, the statutory threshold. By 2008, all member banks in the 


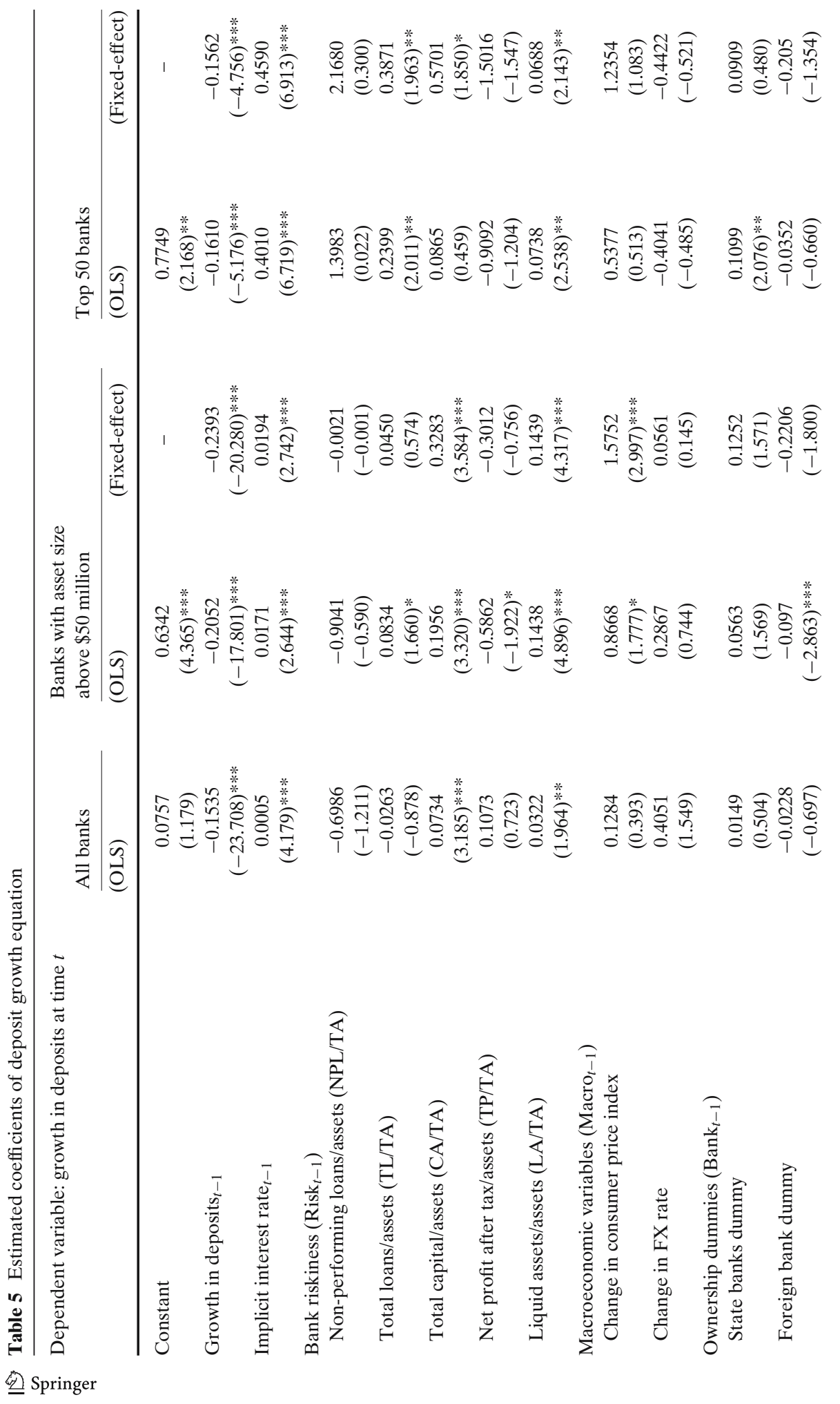




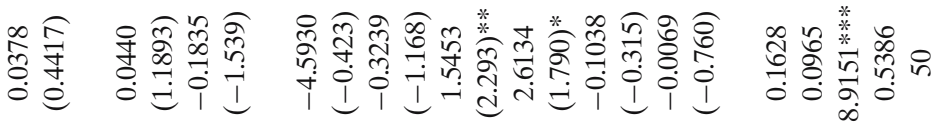

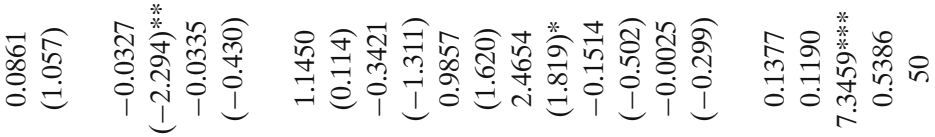

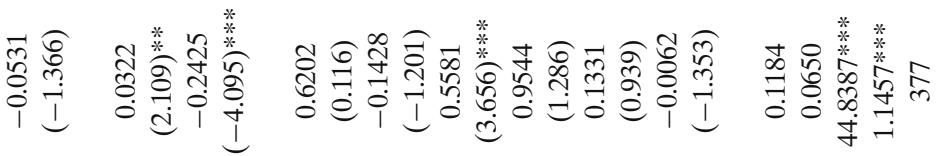

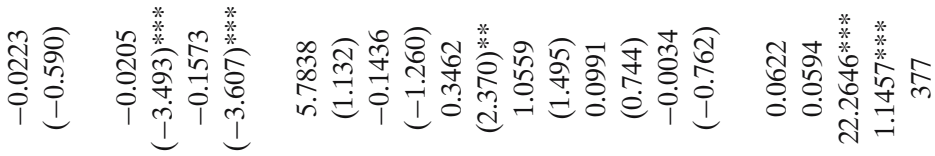

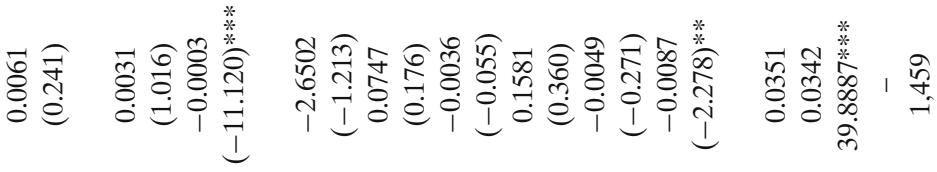

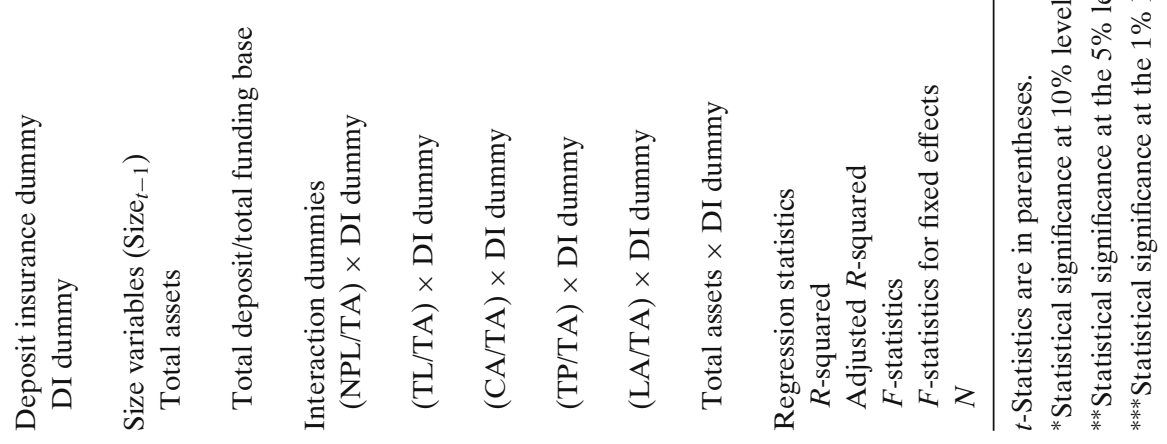




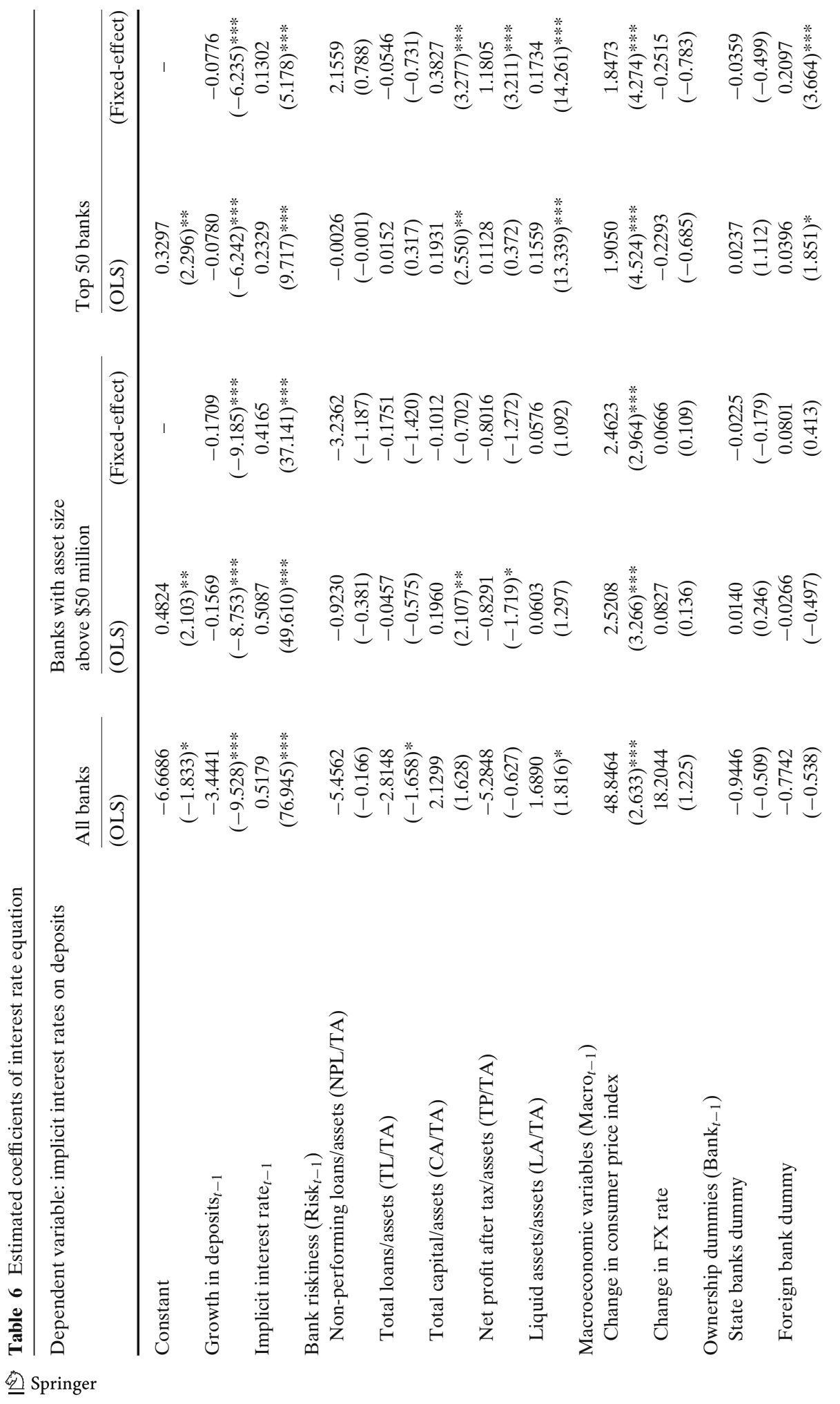




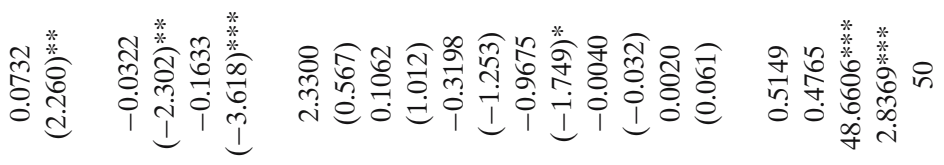

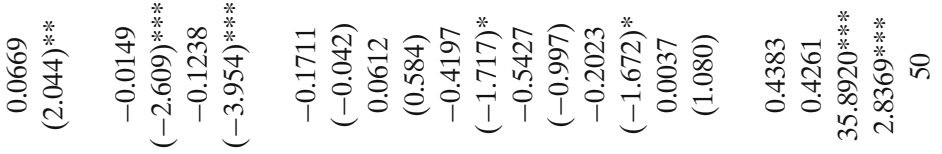

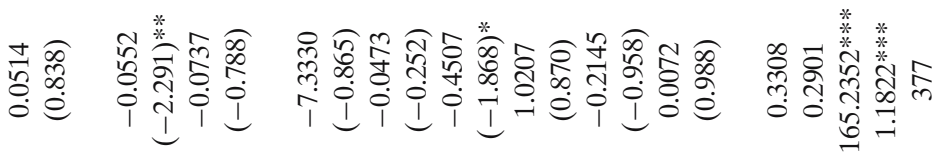

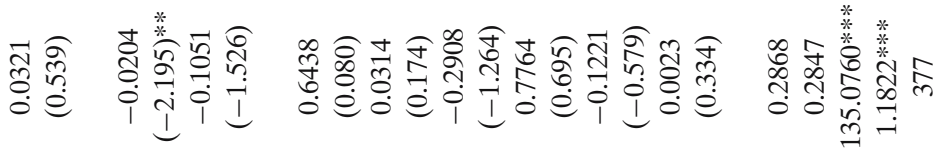

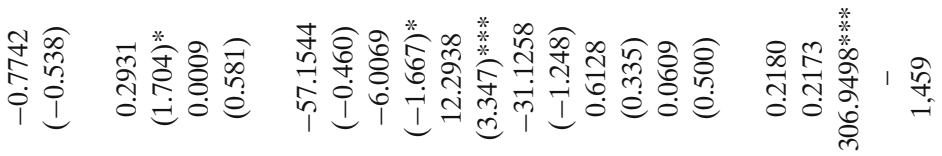

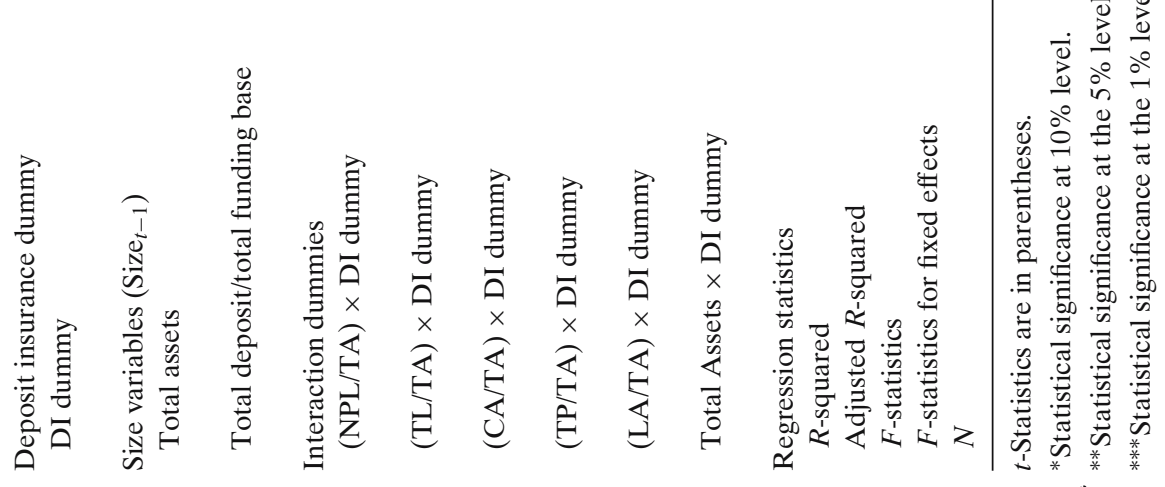




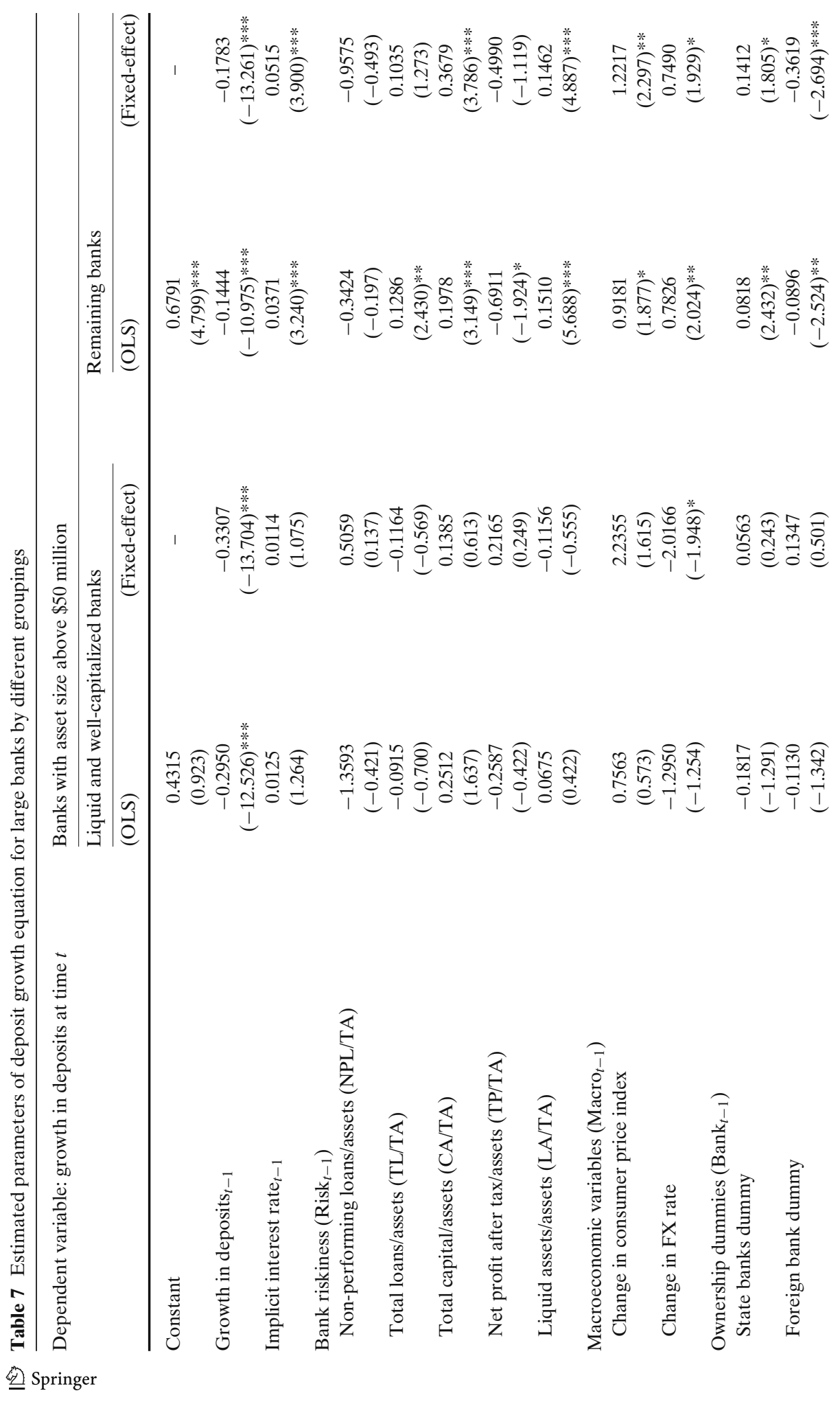




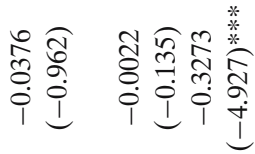

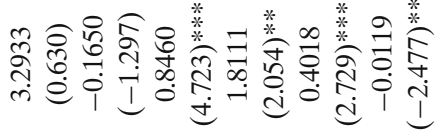

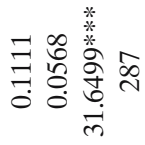

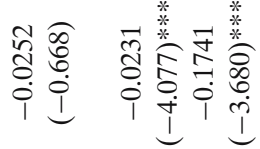

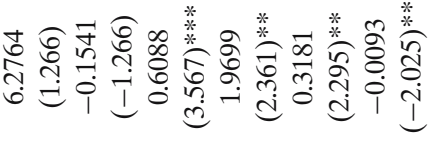

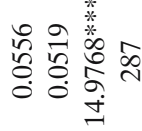

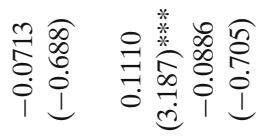

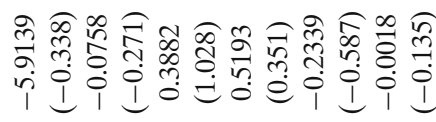

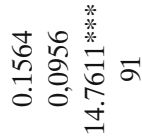

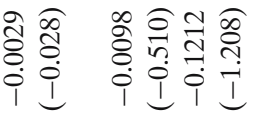

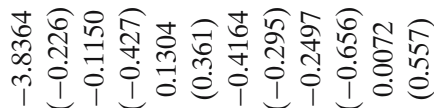

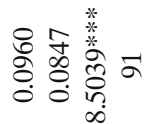

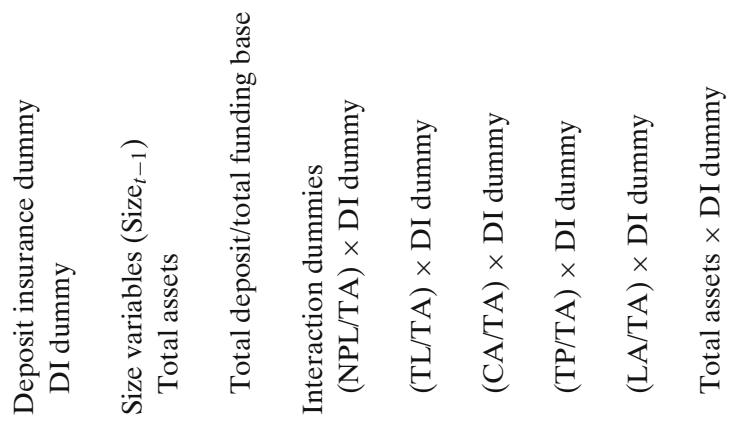




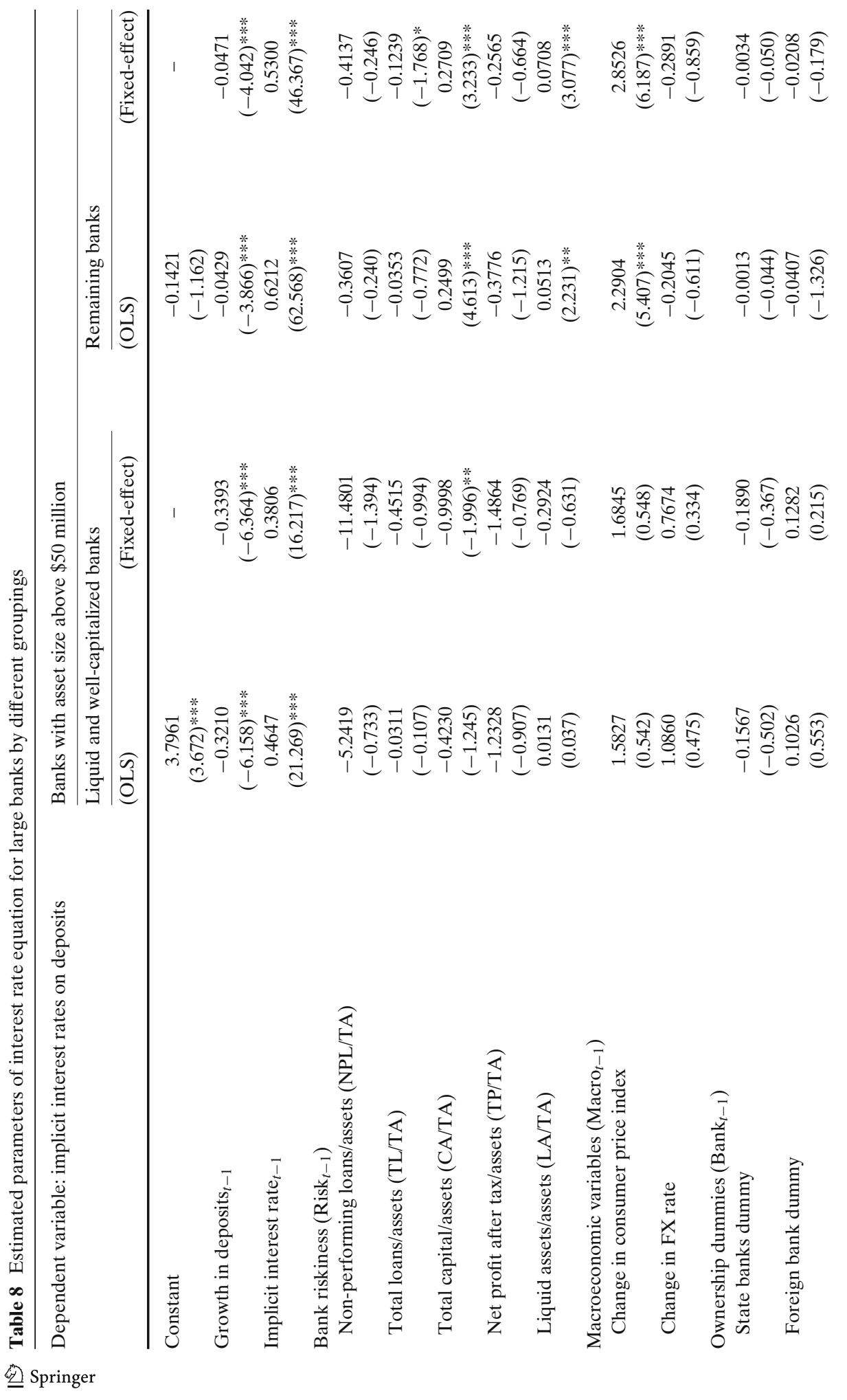




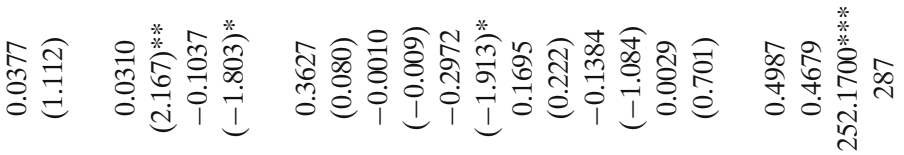

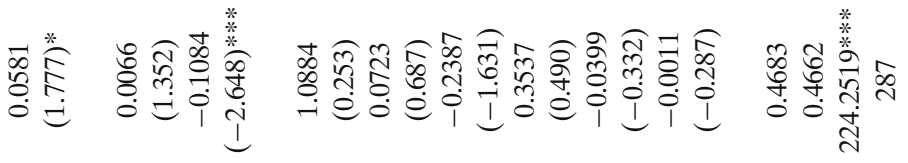

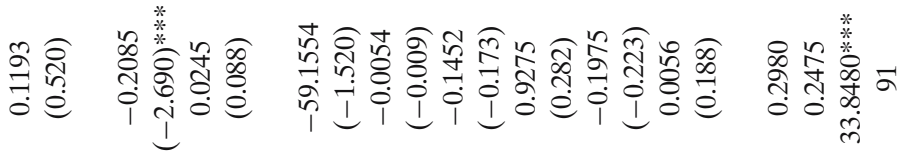

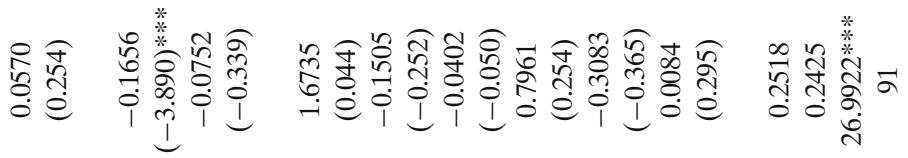

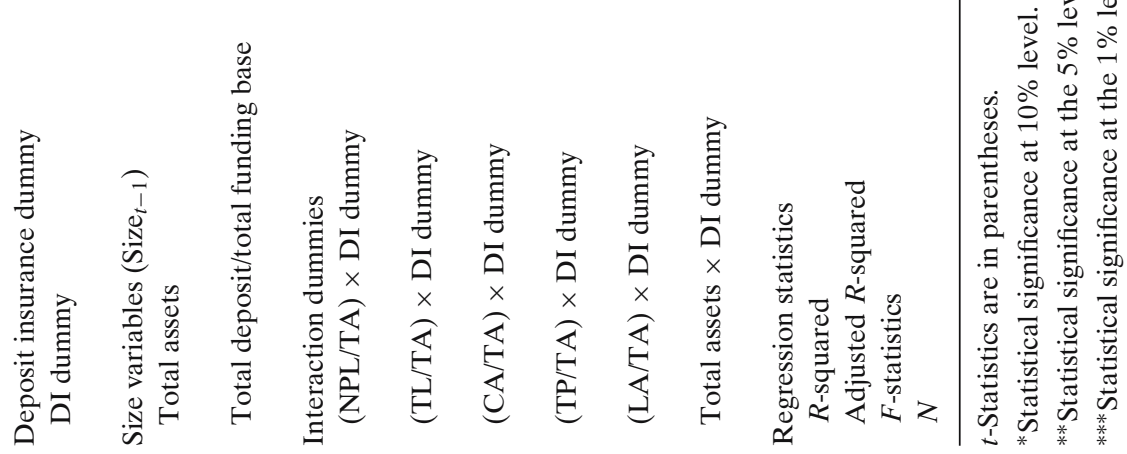


deposit insurance system will be required to have a minimum capital that exceeds the statutory threshold. Therefore, we can attribute most of the increases in the capital-to-asset ratios since 2003 to small banks trying not to lose their licenses to collect deposits. We confirm this supposition with the large significant coefficient of interaction dummy for the capital-to-asset ratios of small banks.

One variable that had no effect on disciplining banks by depositors is the nonperforming loans-to-asset ratio. Although this ratio is considered an important variable in identifying banks' riskiness in the developed markets, it has no significant impact on the deposits and/or interest rates paid by banks in the Russian Federation. It appears that because of the treatment of nonperforming loans by the CBR, it is hard to identify the impact of a change in the bad loans on deposits or interest rates by using quarterly data. There is a strict write-off regulation, which has been in effect since 2002, that does not allow banks to carry nonperforming assets on their balance sheets for longer than 90 days. Now that banks comply with this requirement (or roll them over into new loans), the nonperforming loans-to-asset ratios of banks are not significant in the estimated depositor discipline equations.

Although we use relatively large banks to demonstrate the existence of depositors' reaction for excessive risk-taking, it is possible that deposit growth is influenced by other factors. For example, there might be strong depositor confidence in the large banks because of the possible existence of implicit guarantees such as "too-big-tofail" (TBTF) protection. In addition, there might be aggressive marketing strategies that less-risky, better-capitalized, and more-liquid banks pursue to improve their market shares. Or, perhaps by investing in new branches, personnel, and advertising, etc., large banks can achieve higher deposit growth without offering higher interest rates. These findings might be interpreted as market discipline. To identify the factors that contribute to depositors' reaction to bank riskiness, we reclassify the banks in our sample according to their capitalization and liquidity. We separate banks with asset more than $\$ 50$ million (369 banks) into two groups according to their capital and liquidity ratios. We label banks with liquidity and capital-to-asset ratios above the median as "Liquid and Well-Capitalized Banks" and label the other banks as "Remaining Banks."

Tables 7 and 8 present the estimated parameters of deposit growth and interestrate equations for Liquid and Well-Capitalized Banks, and for the Remaining Banks. According to the OLS and fixed-effect estimates, none of the risk factors has a significant impact on the deposit growth, nor on interest paid on deposits in the subsample of Liquid and Well-Capitalized Banks. Depositors perceive these banks as unlikely to fail. Tables 7 and 8 show that when the assets of the liquid and wellcapitalized banks increase the growth rate of deposits also increases, even though interest rates paid on deposits by these banks decline.

However, among the Remaining Banks, there is no indication that depositors perceive that these banks are safe. In the subsample of less capitalized and lessliquid banks, depositors exercise discipline based on capitalization and liquidity. When placing funds in such banks, depositors seek banks with better capitalization. Depositors also prefer banks with higher liquidity. We observe that interaction dummies with deposit insurance, excluding nonperforming and the total loans, are all significant. Even though size interaction dummy has the wrong sign, it is mostly due to large banks' loss of market share. 
Both capital and liquidity ratios are significant and have positive coefficients in the interest-rate equations for undercapitalized and/or illiquid banks. The higher interest rates paid by these banks, even though they increase their capitalization and liquidity, is due to their efforts to improve their market share and to qualify for joining the deposit insurance system. Furthermore, in 2003 CBR introduced new requirements for capital and liquidity adequacy for commercial banks. Banks anticipated that they have to improve their balance sheets before they could join the deposit insurance system. Hence, we do not observe any depositor discipline after the introduction of deposit insurance.

\section{Conclusion}

In this paper, we measure the extent of market discipline imposed by depositors on the banks in the Russian Federation. Banking in the Russian Federation has developed rapidly since the Russian financial crisis in 1998. Since the crisis, the banking industry has consolidated and improved its role in financial intermediation. A new banking law was introduced with the intent of improving the prudential requirements for banks in line with the Basel II Accord principles. In the meanwhile, depositors had become aware of banks' risk-taking behavior.

We find that depositors impose limited market discipline on bank risk-taking. Depositors adjust the level of their funds in the banks based on the banks' liquidity and capital adequacy. This result on depositor discipline is consistent with the results from other emerging markets. Similar behavior of depositors in other emerging markets suggests that the depositors are not completely informed about the risktaking behavior of banks, but prefer highly capitalized banks.

In addition to highly capitalized banks, depositors also prefer highly liquid banks. Moreover, depositors perceive that there is safety in larger banks that are more liquid and well-capitalized compared to other large banks.

Risk factors are not significant in demanding higher interest rates on deposits. Estimations on less-capitalized and/or less-liquid large banks indicate that these banks pursue aggressively high pricing strategies to increase their external funds. In doing so, these banks would be qualified to join the deposit insurance system and also would be able to satisfy the minimum requirements of the CBR. However, we observe that the establishment of the deposit insurance system has not yet been effective in determining depositor behavior.

\section{References}

Barajas A, Steiner R (2000) Depositor behavior and market discipline in Colombia. International Monetary Fund Seminar Series 51:1-39, September

Barth JR, Dopico LG, Nolle DE, Wilcox JA (2002) An international comparison and assessment of the structure of bank supervision. Corp Financ Rev 6:9-34, May/June

Barth JR, Nolle DE, Phumiwasana T, Yago G (2003) A cross-country analysis of the bank supervisory framework and bank performance. Financ Mark Inst Instrum 12:67-120

Barth JR, Caprio G, Levine RE (2004) Bank regulation and supervision: what works best? J Financ Intermed 13:205-248 
Berger AN (1991) Market discipline in banking. Proceedings of a conference on bank structure and competition. Federal Reserve Bank of Chicago, pp 419-437

Billet MT, Garfinkel JA, O'Neal ES (1998) The cost of market versus regulatory discipline in banking. J Financ Econ 48:333-358

Bliss RR, Flannery MJ (2002) Market discipline in the governance of U.S. bank holding companies: monitoring vs. influence. European Finance Review 6(3):361-395

Calomiris CW, Kahn CM (1991) The role of demandable debt in structuring optimal banking arrangements. Am Econ Rev 81:497-513

Calomiris CW, Powell A (2001) Can emerging market bank regulators establish credible discipline? The case of argentina, 1992-1999. In: Frederic SM (ed) Prudential supervision: what works and what doesn't? University of Chicago Press, Chicago

Central Bank of Russian Federation (2005) Banking supervision report 2004. Moscow

Central Bank of Russian Federation (2006) Banking supervision report 2005. Moscow

Evanoff DD, Wall LD (2002) Measures of the riskiness of banking organizations: subordinated debt yields, risk-based capital and examination ratings. J Bank Financ 26:989-1009

Flannery MJ (1998) Using market information in prudential bank supervision. J Money Credit Bank 30:273-305

Flannery MJ (2001) The faces of market discipline. J Financ Serv Res 20:107-119

Flannery MJ, Nikolova S (2004) Market discipline of US financial firms: recent evidence and research issues. In: Hunter W, Kaufman G, Borio C, Tsatsaronis K (eds) Market discipline across countries and industries. MIT Press, Cambridge

Furfine CH (2001) Banks as monitors of other banks: evidence from the overnight federal funds market. J Bus 74(1):33-57

Gilbert AR (1990) Market discipline of bank risk: theory and evidence. Federal Reserve Bank of Saint Louis Review 72:3-18

Ghosh S, Das A (2003) Market discipline in the Indian banking sector: an empirical exploration. NSE Research Initiative, Working Paper

Goldberg LG, Hudgins SC (1996) Response of uninsured depositors to impending S\&L failures: evidence of depositor discipline. Q Rev Econ Finance 36:311-325

Goldberg LG, Hudgins SC (2000) Depositor discipline and changing strategies for regulating thrift institutions. J Financ Econ 63:263-274

Hall JR, King TB, Meyer AP, Vaughan MD (2002) Did FDCIA enhance market discipline? A look at evidence from the jumbo-CD market. Working Paper, Federal Reserve Bank of St. Louis

Jagtiani JJ, Lemieux CM (2001) Markets discipline prior to failure. J Econ Bus 53:313-324

Jagtiani JJ, Kaufman GG, Lemieux CM (2002) The effect of credit risk on bank and bank holding companies bond yield: evidence from the post-FDCIA period. J Financ Res 25:559-576

Karas A, Pyle W, Schoors K (2004) How do Russian depositors discipline their banks? Bank of Finland Seminars

Martinez-Peria MS, Schmukler SL (2001) Do depositors punish banks for bad behavior? Market discipline deposit insurance and banking crises. J Finance 56(3):1029-1051

Mondschean TS, Opiela TP (1999) Bank time deposit rates and market discipline in Poland: the impact of state ownership and deposit insurance reform. J Financ Serv Res 15:179-196

Morgan DP, Stiroh KJ (2001) Market discipline of banks: the asset test. J Financ Serv Res 20:195-208

Park S, Peristiani S (1998) Market discipline by thrift depositors. J Money Credit Bank 30:347-364

Peresetsky A, Karminsky A, Golovan S (2006) Retail business: heterogeneity of interest rates on private deposits. NES Working Paper, 2006/57

Sironi A (2002) Strengthening banks' market discipline and leveling the playing field: are the two compatible? J Bank Financ 26:1065-1091

Ungan EA, Caner S (2004) Market discipline in supervising Turkish banks. European Financial Management Association, Merton Miller PhD Seminar Series, Basel 